\title{
Annual growth dynamics of Posidonia oceanica: contribution of large-scale versus local factors to seasonality
}

\author{
Teresa Alcoverro', Carlos M. Duarte ${ }^{2}$, Javier Romero ${ }^{1, *}$ \\ 'Departament d'Ecologia, Universitat de Barcelona, Diagonal 645, E-08028 Barcelona, Spain \\ ${ }^{2}$ Centre d'Estudis Avançats de Blanes, CSIC, Camí de Sta. Barbara s/n, E-17300 Blanes (Girona), Spain
}

\begin{abstract}
The seasonal growth pattern of the seagrass Posidonia oceanica (L.) Delile was examined in 5 meadows in NE Spain to assess the relative importance of large-scale versus local factors in controlling the seasonal patterns observed. Large-scale seasonal forcing, resulting from changes in light and temperature associated with the solar cycle, was assessed from the coherence of seasonal growth patterns among the meadows and accounted for 46 and $43 \%$ of variability in shoot size and growth, respectively. The local component of seasonality, which results from local variation in environmental variables (e.g. nutrients, dissolved inorganic carbon, redox potential) was assessed as the differences in the annual time course of shoot size and growth among the meadows, and accounted for 9 and $12 \%$ of the rariability, respectively. These results support the contention that seagrass seasonality is primarily controlled by the solar cycle, and secondarily by seasonal changes in the environment which are at least in part caused by the temporal variability of seagrass growth. This indirect link between light and temperature and local conditions needs to be taken into account to interpret correlations between such variables and seagrass growth.
\end{abstract}

KEY IVORDS: Growth - Primary production - Seagrass $\cdot$ Posidonia oceanica S Seasonality $\cdot$ Nutrients

\section{INTRODUCTION}

Temperate seagrass meadows exhibit significant seasonal fluctuations in biomass and productivity (Zieman 1975, Duarte 1989). It is currently believed that these seasonal variations are basically controlled by 2 factors related to solar energy, irradiance and temperature (e.g. Sand-Jensen 1975, Pérez \& Romero 1992). If this were true, then individual seagrass species should show coherent seasonal variation at a mesoscale (about $100 \mathrm{~km}$ ). Alternatively, it may be that seasonal changes in the availability of other resources disrupt the expected large-scale coherence by introducing local variability

Among such local factors, sediment characteristics (e.g. nutrients, redox potential) could have a key role (Orth \& Moore 1986, Marshall et al. 1987, Short 1987,

\footnotetext{
- Addressee for correspondence
}

Fourqurean 1992). For instance, nutrient availability is controlled locally by land inputs, sediment dynamics and type (Short 1987, Hemminga et al. 1991), and influences of associated biota (Aller 1980, Yamada \& Kayama 1987). In addition sediment nutrients often become depleted during summer, when seagrass requirements are highest (Pérez et al, 1991). Neighbouring seagrass meadows growing under contrasting sediment characteristics may, therefore, exhibit different seasonal dynamics (Powell et al. 1989). However, since seagrasses are able to deplete local resources only when temperature and irradiance allow fast growth, large-scale and local factors may interact in the control of seasonal seagrass dynamics (Pedersen \& Borum 1992).

Posidonia oceanica (L.) Delile is the dominant seagrass species in Mediterranean coastal waters, covering extensive areas in the infralittoral and extending down to $35 \mathrm{~m}$ of depth (Duarte 1991). Previous studies demonstrated strong seasonality of $P$. oceanica growth 
with an early summer maximum and a fall. minimum (Ott 1980, Caye \& Rossignol 1983, Bay 1984, Wittman 1984, Romero 1989a). Yet, P. oceanica seasonality may deviate from this pattern with maximal growth in winter (e.g. Buia et al. 1992), suggesting the importance of factors other than light and temperature in regulating the seasonal pattern.

Here we evaluate the relative contribution of largescale versus local factors in controlling the seasonality of Posidonia oceanica. We do so by examining the annual growth pattern, biomass and nutrient content of $P$. oceanica in 5 meadows with contrasting biomass and sediment features. The effect of large-scale factors would be reflected by the coherence among meadows and a common pattern correlated with irradiance, and local factors by deviations from this common pattern.

\section{METHODS}

The study was conducted in 4 Posidonia oceanica meadows along the NE coast of Spain (Fig. 1). In 2 meadows (Port-Lligat and Giverola), the study site was located towards the upslope limit of the plant distribution ( $5.0 \mathrm{~m}$ depth); in 1 meadow (Blanes), the study site was close to the deep limit (13 $\mathrm{m}$ depth); in the Medes meadow, 2 study sites were chosen, one near the shallow limit and the other 1 near the deep limit (called respectively shallow Medes and deep Medes).

We evaluated leaf growth by marking shoots on 8 to 10 visits ( 8 visits on Blanes, 9 visits on Giverola, shallow Medes and Port-Lligat, 10 visits on deep Medes) from September 1990 to January 1992. At each site, 10 shoots were marked on each visit to estimate leaf

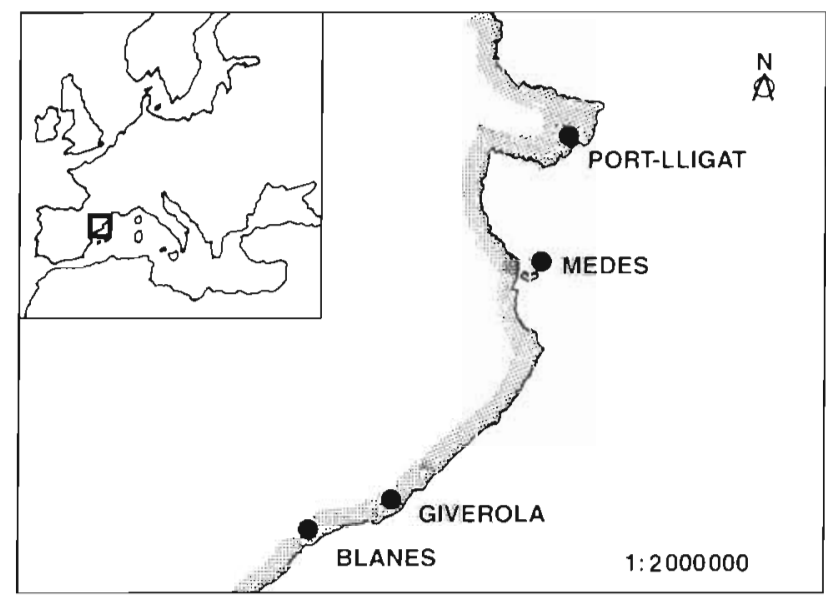

Fig. 1 Location of the 4 Posidonia oceanica meadows in NE Spain where this work was performed. In the Medes meadow. 2 sites ( 1 shallow and 1 deep) were studied production using a modified Zieman method (Zieman 1974, Romero 1989a) and the 10 shoots marked on the previous visit were collected. All leaves within a shoot were marked together by punching 2 parallel holes just above the ligula of the outermost leaf with a hypodermic needle. Leaf elongation was measured as the displacement of holes relative to the ligula of the oldest and non-growing leaf. Harvested shoots were rinsed and the epiphytes were removed with a razor blade. Elongation and total length of each leaf were measured to the nearest $\mathrm{mm}$, and then the old and the new tissues were dried $\left(70^{\circ} \mathrm{C}\right.$ to constant weight) and weighed separately.

Subsamples were kept for nitrogen, phosphorus and carbon analysis. Density of shoots was counted in $40 x$ $40 \mathrm{~cm}$ quadrats (5 replicate samples), and these data were used to obtain production per unit area (Romero 1989a).

The production of new leaves was computed as the number of unmarked leaves per shoot and per unit time, and the leaf loss rate as described in Romero (1989b):

$$
\operatorname{LLR}=\left(L_{t}+N L_{t}-L_{t^{\prime}}\right) /\left(t^{\prime}-t\right)
$$

where LLR is the leaf loss rate (leaves shoot ${ }^{-1} \mathrm{~d}^{-1}$ ), $L_{t}$ and $L_{t}$ are the number of leaves per shoot at time $t$ and $t^{\prime}$, and $N L_{t}$ is the number of new leaves which appeared between time $t$ and $t^{\prime}$.

Total carbon and nitrogen were determined using a Carlo-Erba CHN Analyzer and phosphorus was determined by induced coupled plasma after acid digestion of the material (Sommers \& Nelson 1972, Mateo \& Sabaté 1993).

On each visit, 3 replicate sediment cores to about $5 \mathrm{~cm}$ of depth into the sediments were collected. The cores were frozen, the top $2 \mathrm{~cm}$ sliced and the interstitial water isolated after a treatment to extract ammonium (20 $\mathrm{ml}$ of $2 \mathrm{M} \mathrm{KCl}$, shaking for $15 \mathrm{~min}$ ) by centrifugation $(3000 \times$ g, $10 \mathrm{~min}$; see Alef \& Kleiner 1986 , López 1993). Nutrient concentrations (ammonium, nitrite, nitrate and phosphate) were measured in an autoanalyzer following standard methods (Grasshoff et al. 1983). Since a high vertical heterogeneity does exist in vertical distribution of nutrients in seagrass sediments (Vidal 1988), these values have been taken only as an indicator of the seasonality of nutrient content in interstitial waters, and thus do not represent the total nutrient availability to the plant. In addition to these sediment samples, in spring we collected 3 cores reaching $15 \mathrm{~cm}$ of depth into the sediment from each sampling station except Blanes to measure redox potential. These samples were transported to the laboratory under refrigeration, and then frozen. Redox potential was measured immediately after thawing and homogenizing $1 \mathrm{~cm}$ thick slices using redox and 
Table 1. Basic features of the Posidonia oceanica meadows studied. Data on organic matter (OM) of the sedinent, and dissolved inorganic phosphorus and nitrogen of the pore water are annual means. Redox potential is the average of the top $20 \mathrm{~cm}$. When available, standard deviations are given in parentheses. The probability that the properties were similar in all meadows (Tukey HSD test) are given. ns: not significant

\begin{tabular}{|c|c|c|c|c|c|c|}
\hline Variable & Blanes & Giverola & $\begin{array}{l}\text { Deep } \\
\text { Medes }\end{array}$ & $\begin{array}{c}\text { Shallow } \\
\text { Medes }\end{array}$ & Port-Lligat & $\mathrm{p}$ \\
\hline Organic content (mg OM $\mathrm{cm}^{-3}$ ) & $19.26(9.07)$ & $25.94(5.75)$ & $42.02(16.8)$ & $41.83(7.1)$ & $65.27(40.0\}$ & 0.000 \\
\hline Shoot density (shoots $\mathrm{m}^{-2}$ ) & 78 & 111 & 153 & 410 & 627 & \\
\hline Redox potential (mV) & - & $630(50)$ & $98(23)$ & $74(16)$ & $-88(56)$ & \\
\hline Dissolved inorganic nitrogen $\left(\mu \mathrm{mol} \mathrm{l}^{-1}\right)$ & $645(776)$ & $297(376)$ & $533(471)$ & $402(385)$ & $520(401)$ & ns \\
\hline Dissolved inorganic phosphorus ( $\mu \mathrm{mol} \mathrm{l}^{-1}$ ) & $6.0(8.4)$ & $10.8(12.3)$ & $28.9(28.6)$ & $43.4(59.7)$ & $25.1(29.7)$ & 0.001 \\
\hline 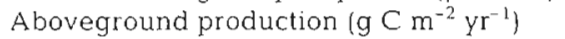 & 31.0 & 51.0 & 87.4 & 252.5 & 215.2 & 0.000 \\
\hline
\end{tabular}

reference electrodes. Organic matter content of the sediment was obtained by burning dry sediment subsamples at $450^{\circ} \mathrm{C}$ for $2 \mathrm{~h}$.

Surface irradiance was obtained from a station close to the study area which recorded radiation values continuously. Radiation data corrrespond to total surface irradiance at noon averaged monthly. Temperatures were obtained from López (1993) and correspond to the same sites and periods in which this work was performed.

We used a 2-way ANOVA to partition the observed variance in seagrass growth and shoot size into variance among meadows and seasonal variance. This was in turn partitioned into a large-scale component, assessed from the variance during sampling events (time), and a local component, assessed from the variance in seasonal patterns among meadows (i.e. the interaction between meadow and time). Multiple comparison between means were based on the Tukey HSD test. Non-parametric comparisons of significant differences between meadows in the nutrient contents of the leaves during the year were based on the Wilcoxon ranked sign test (Sokal \& Rohlf 1981).

\section{RESULTS AND DISCUSSION}

The meadows studied had coarse, sandy sediments with low organic matter contents (19.3 to $42.0 \mathrm{mg}$ OM $\mathrm{cm}^{-3}$ ), except for that in Port-Lligat, which was siltier and had a much higher organic content (average of 65.3 , but up to $90 \mathrm{mg} \mathrm{OM} \mathrm{cm} \mathrm{cm}^{-3}$, see Table 1). Similarly, sediments in Port-Lligat tended to be reduced (redox potential -33 to $-150 \mathrm{mV}$ ), compared to those in the other meadows, which had higher $(70$ to $630 \mathrm{mV}$ ) redox potentials. These differences result mostly from the interaction of seagrass biomass and exposure to waves. Meadows at Blanes, Giverola and the deep Medes were sparse (50 to 150 shoots $\mathrm{m}^{-2}$, Table 1) and did not, therefore, supply much organic matter to the sediments. In contrast, the meadow at Port-Lligat was quite dense ( $>600$ shoots $\mathrm{m}^{-2}$ ) and able to supply considerable organic matter to the sediments of this sheltered bay, whereas that supplied by the similarly dense meadow in shallow, exposed Medes Island would be mostly advected outside the bed. Dissolved nitrogen concentrations in interstitial pore waters did not differ much among meadows, whereas phosphate concentrations were 3 to 4 times lower in the patchy meadows at Blanes and Giverola (Table 1).

Average water temperatures ranged from a minimum of $12^{\circ} \mathrm{C}$ in February to a maximum of $23.3^{\circ} \mathrm{C}$ in September (López 1993). Light intensity ranged from a minimum of $102 \mathrm{~W} \mathrm{~m}^{-2}$ in January to a maximum of $427 \mathrm{~W} \mathrm{~m}^{-2}$ in July. Dissolved nutrient concentration in interstitial pore waters also showed substantial seasonal variability, with minimum concentrations often observed in early spring (Fig. 2). These low concentrations in early spring were particulary remarkable for phosphate, which afterwards declined below the detection limit in the sediments of all the meadows studied.

Posidonia oceanica shoots were largest at the Blanes meadow (Table 2), bearing about 7 leaves shoot ${ }^{-1}$, compared to 5 to 6 leaves shoots ${ }^{-1}$ at the other meadows. Average shoot growth differed significantly, albeit not substantially among meadows (Table 2); shoots grew significantly (Tukey HSD test, p < 0.01) slower at Port-Lligat (Table 2). Annual aboveground production differed among meadows, and was highest in the densest meadows (Table 1). Leaves in all meadows showed low average nutrient content, particularly phosphorus (Table 2) where the concentrations were sufficiently low to suggest a potential growth limitation (Duarte 1990), except for those in leaves from deep Medes which tended to have significantly higher nitrogen and phosphorus concentrations throughout the year (Wilcoxon test, $\mathrm{p}<0.01$, Table 2 ).

Shoot size and growth showed considerable seasonal variability. Shoots were largest in late summer 

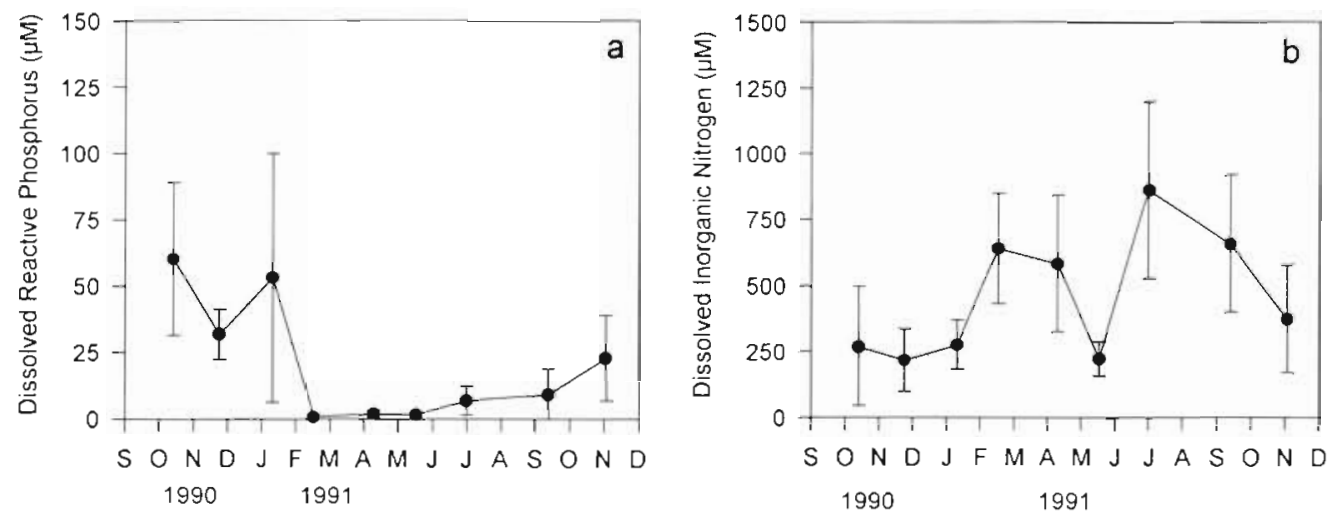

Fig. 2. Average seasonal changes in (a) soluble reactive phosphorus and (b) dissolved inorganic nitrogen (nitrite + nitrate + ammonium) concentrations in the interstitial waters of the Posidonia oceanica meadows. Dots represent the nutrient concentration averaged over the 5 sampling stations and vertical bars are standard deviations

and declined in size during fall, similar to the pattern of shoot growth (Fig. 3a, b). This pattern of shoot size corresponded with high leaf loss following the first storms in fall, which was followed by a period of fast production of new leaves in September-October (Fig. 3c, d). Leaf nutrient concentrations also showed a distinct seasonality; nitrogen and phosphorus concentrations increased during winter (Fig. 4) to reach average concentrations close to those believed to suffice for balanced seagrass growth $1.8 \%$ dry wt for nitrogen and $0.2 \%$ dry wt for phosphorus; Duarte 1990). Yet, concentrations declined by almost $50 \%$ from the February maxima to the minimum value in late summer (Fig. 4), reaching levels that may limit seagrass growth. Hence, nitrogen and phosphorus tended to vary synchronously (coefficient of linear regression: $r=0.92, p<0.001$ ).

Shoot size was positively correlated with irradiance $(r=0.69, p<0.001 ;$ Fig 5$)$, and this is due to both the seasonal growth pattern (Fig. 3b) and to the leaf loss seasonal pattern (Fig. 3c) which allows large biomass accumulation during summer. The correlation between growth and irradiance was weaker $(\mathrm{r}=0.35, \mathrm{p}=$ 0.02 , Fig. 5), and this is mostly attributable to the low growth rates during summer, when irradiance is high, and the relatively high winter growth rates (Fig. 3b). Thus, it is clear that a substantial part of seasonal variability remains unexplained by the light cycle, indicating that other local factors may assert control over growth during parts of the growing season.

Among these other factors, nutrient availability is thought to be of key importance, and seasonal nutrient limitation of other seagrasses in the Mediterranean has been demonstrated in the past (Pérez \& Romero 1992). Nutrient limitation could result from nutrient depletion due to uptake by the plants (Fig. 2a, b), coupling nutrient availability and the solar cycle through their combined effect on plant growth. This possibility is supported by the observed decline in sediment nutrient concentrations following periods of fast growth (Fig. 2).

Factors other than nutrient availability can also affect the seasonality of plant growth, such as dissolved inorganic carbon availability (Durako 1993) or low redox potentials. Daily anoxia periods interfere with nitrogen metabolism or root growth (Morris 1984, Morris \& Dacey 1984, Marshall et al. 1987), and these periods are more likely to occur in summer, when bacterial activity in the sediment and litter decay are highest (Romero et al. 1992, López 1993) and should differ strongly among sites (Table 1).

Table 2. Posidonia oceanica. Average (SD) shoot growth, shoot size, and leaf dynamics and nutrient contents for the 5 meadows studied, and the probability that their properties were similar (ANOVA; ns: $p>0.05$ ). Correlations between shoot growth and Iight for each meadow are also shown $(* p<0.05 ; \cdots p<0.01 ; \cdots p<0.001)$

\begin{tabular}{|c|c|c|c|c|c|c|}
\hline Variable & Blanes & Giverola & $\begin{array}{l}\text { Deep } \\
\text { Medes }\end{array}$ & $\begin{array}{c}\text { Shallow } \\
\text { Medes }\end{array}$ & Port-Llıgat & $\mathrm{p}$ \\
\hline Shoot size $\left(\mathrm{cm}^{2}\right.$ shoot $\left.{ }^{-1}\right)$ & $125.8(7.95)$ & $103.14(4.9)$ & $114.66(8.05)$ & $106.9(4.8)$ & $108.6(6.6)$ & ns \\
\hline Number of leaves (leaves shoot ${ }^{-1}$ ) & $7.0(1.2)$ & $6.0(0.5)$ & $5.9(1.3)$ & $5.9(0.7)$ & $5.1(0.9)$ & 0.0075 \\
\hline Growth $\left(\mathrm{cm}^{2}\right.$ shoot $\left.{ }^{-1} \mathrm{~d}^{-1}\right)$ & $0.774(0.055)$ & $0.807(0.038)$ & $0.785(0.058)$ & $0.849(0.032)$ & $0.573(0.035)$ & 0.0004 \\
\hline Leaf carbon (\% dry wt) & $34.01(2.95)$ & $36.17(1.18)$ & $36.75(2.35)$ & $36.13(2.69)$ & $36.16(1.96)$ & ns \\
\hline Leaf nitrogen ( $\%$ dry $w \mathrm{t}$ ) & $1.87(0.63)$ & $1.73(0.83)$ & $2.40(0.39)$ & $2.17(0.31)$ & $1.75(0.32)$ & 0.01 \\
\hline Leaf phosphorus ( $\%$ dry wt) & $0.119(0.04)$ & $0.138(0.03)$ & $0.161(0.03)$ & $0.156(0.02)$ & $0.120(0.05)$ & 0.01 \\
\hline $\mathrm{C}: \mathrm{N}: \mathrm{P}$ (by atoms) & $772: 33: 1$ & $703: 27: 1$ & $598: 32: 1$ & $631: 30: 1$ & $805: 31: 1$ & \\
\hline Growth vs light & $0.61^{\circ}$ & $0.21 \mathrm{~ns}$ & $0.50^{\circ}$ & $0.34 \mathrm{~ns}$ & $0.73^{\cdots}$ & \\
\hline
\end{tabular}



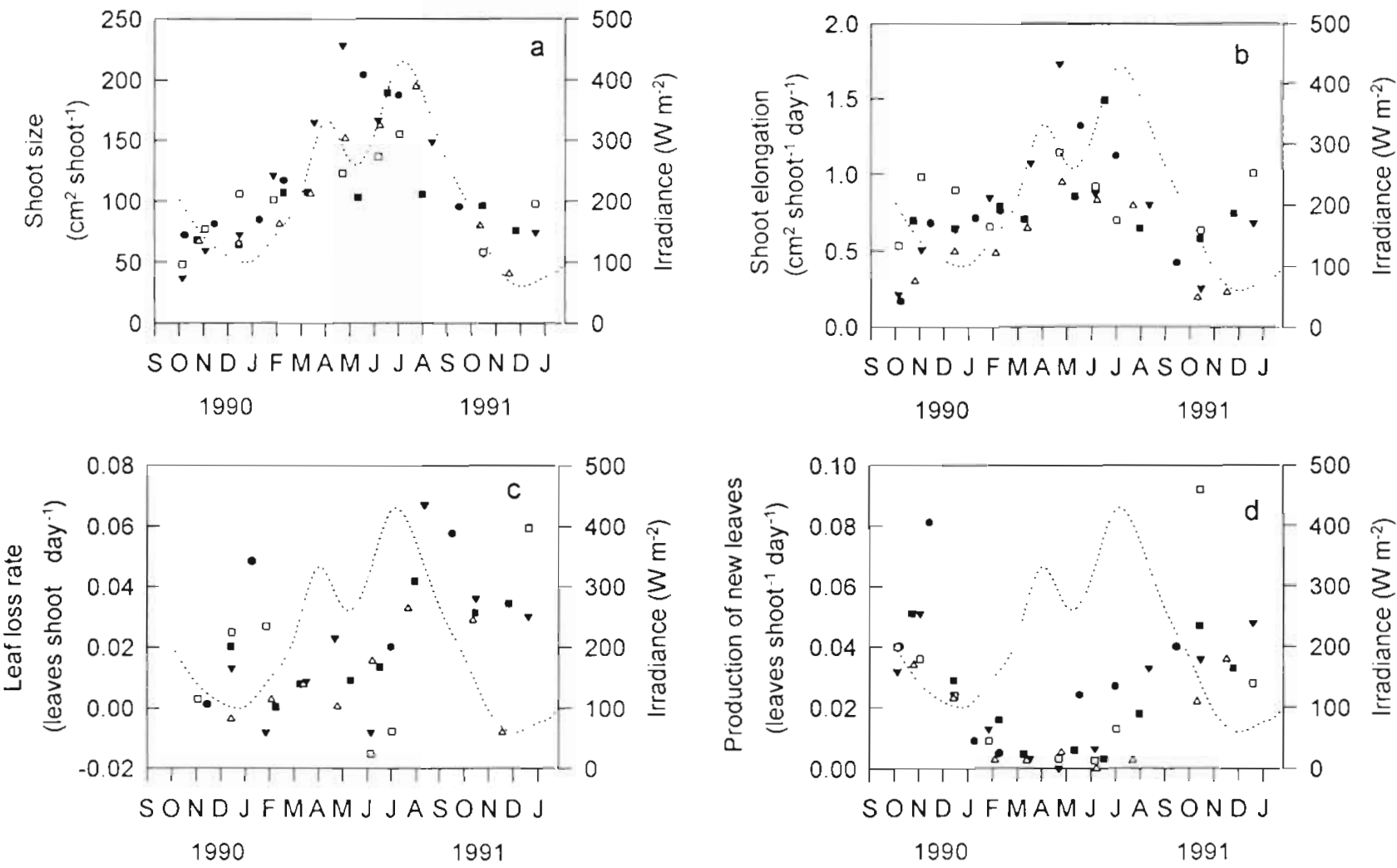

Fig. 3. Posidonia oceanica. Seasonal changes in (a) shoot size, (b) growth, (c) rate of leaf loss and (d) production of new leaves of the 5 sites studied: Blanes ( $)$, Giverola ( $\mathbf{})$, deep Medes (v), shallow Medes (a), and Port-Lligat ( $\Delta$ ). Broken line represents surface urradiance

Hence, seasonality in the meadows examined depends on the interplay between the solar cycles and associated cycles in light and temperature, and local factors (e.g. nutrients, redox potential) which are in turn indirectly coupled to the solar cycle by the plant growth seasonality. The effects of light and temperature should be coherent over large spatial scales, whereas local forc- ing adds local variability to this seasonal pattern. Thus, the growth seasonality of Posidonia oceanica should have 2 components, a large-scale component associated with the solar cycle and derived from the coherence of temperature and light seasonality across the mesoscale, and a local component, derived from the interaction between local factors and seagrass growth.
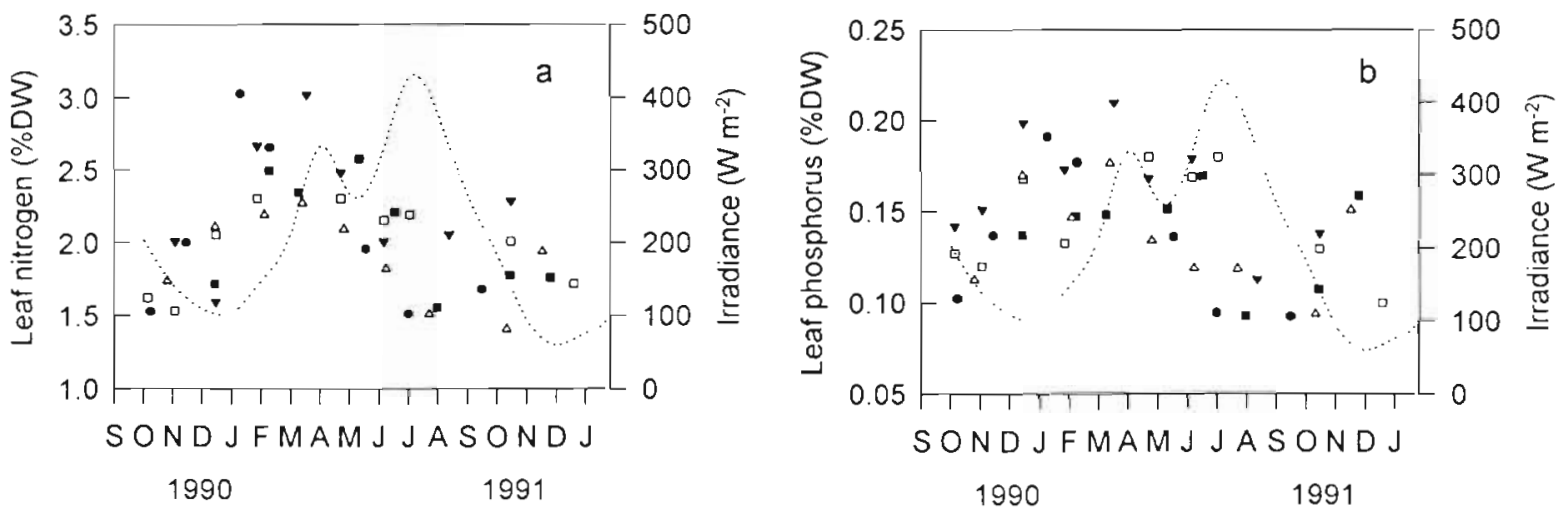

Fig. 4. Posidonia oceanica. Seasonal changes in leaf (a) nitrogen and (b) phosphorus concentrations (as percentage of dry weight) of the 5 sites studied: Blanes $(\bullet)$, Giverola ( $\mathbf{a})$, deep Medes ( $\mathbf{v})$, shallow Medes ( $\square$ ), and Port-Lligat $(\Delta)$. Broken line represents surface irradiance 


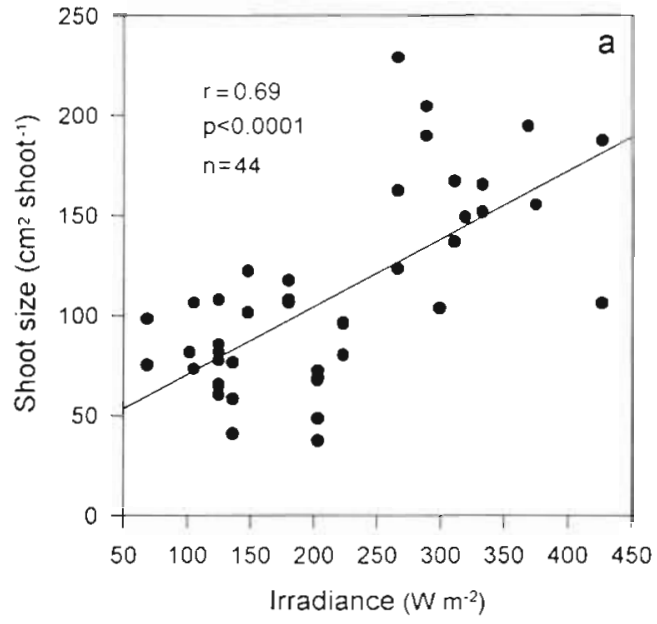

Analysis of variance supported this hypothesis, for, in addition to demonstrating small, albeit significant variability in shoot size (about $5.2 \%$ of the variance) and growth $(6.1 \%$ of the variance) among the meadows, it also revealed significant large-scale and local sources of seasonal variability. Large-scale seasonality accounted for 46.1 and $42.8 \%$ of the variability in shoot size and growth, respectively. Local sources of seasonality, which result in differences in the annual time course of shoot size and growth among meadows, accounted for about 8.9 and $11.8 \%$ of the variability in shoot size and growth, respectively (Table 3). The relative contribution of large-scale and local sources to Posidonia oceanica seasonality also differed among meadows. Large-scale factors became increasingly important where local factors were appropriate for growth, as demonstrated by the stronger correlations among light and growth in Blanes, Deep Medes and Port-Lligat sites (Table 2), whereas local factors seemed to play a greater role at the other 2 sites (Giverola and Shallow Medes).
The results obtained support the hypothesis of a double control of seagrass seasonality. Seagrass seasonality is primarily controlled by the solar cycle, which determines water temperature and light availability and, hence, constrains seagrass metabolism (e.g. Hillman et al. 1990). Secondly, the temporal variability in seagrass growth induced by the solar cycle causes, in turn, seasonal variability in resources (nutrients, dissolved inorganic carbon) and local conditions (redox potential) and feedback control of seagrass growth. An additional component of the seasonal growth pattern of Posidonia oceanica is its ability to store carbon resources in its shoots and rhizomes (Pirc 1985). Hence, P. oceanica is able, unlike other temperate seagrasses (Sand-Jensen 1975), to support substantial growth rates over winter at the expense of starch accumulated in their massive rhizomes over late summer and fall (Pirc 1985). At the same time, our results seem to point out the possibility of nutrient accumulation or efficient recycling that could support the fast growth observed over spring

Table 3. Summary of the analysis of variance to partition the variance in shoot size and growth into different components (as \% of the total variance). The statistical significance of each source of variation is given as in Table 2

\begin{tabular}{|c|c|c|c|c|}
\hline \multirow[t]{2}{*}{ Variable } & \multirow{2}{*}{$\begin{array}{l}\text { Spatial variance } \\
\text { (among meadows) }\end{array}$} & \multicolumn{2}{|c|}{ Seasonal variance } & \multirow{2}{*}{$\begin{array}{c}\text { Error } \\
\text { (among shoots) }\end{array}$} \\
\hline & & $\begin{array}{c}\text { Large scale } \\
\text { (among months) }\end{array}$ & $\begin{array}{c}\text { Local scale } \\
\text { (meadows } \times \text { months) }\end{array}$ & \\
\hline \multicolumn{5}{|l|}{ Shoot size } \\
\hline Variance explained & $5.24 \%$ & $46.06 \%$ & $8.92 \%$ & $39.77 \%$ \\
\hline Degrees of freedom & 4 & 7 & 28 & 635 \\
\hline Mean squares & 31.857 & 160000 & 7751 & 1523 \\
\hline$F$ & $20.9^{\cdots}$ & $104.8 \cdots$ & $5.09 \cdots$ & \\
\hline \multicolumn{5}{|l|}{ Elongation } \\
\hline Variance explained & $6.07 \%$ & $42.82 \%$ & $11.77 \%$ & $39.34 \%$ \\
\hline Degrees of freedom & 4 & 7 & 28 & 635 \\
\hline Mean squares & 2.06 & 8.29 & 0.57 & 0084 \\
\hline$F$ & $24.5^{\prime \cdot}$ & $98.6 \cdots$ & $6.7^{\cdots}$ & \\
\hline
\end{tabular}


and early summer, when sediment nutrients were exhausted (Figs. $2 \& 3$ ).

In summary, we have shown the significance of local conditions in regulating growth and shoot size on an annual basis, especially where these local conditions limit seagrass growth. Consequently, local factors can play a major role in shallow environments where light availability is high, whereas they have a small contribution to the seasonal growth patterns of light-limited plants or those growing in nutrient-rich environments. Local conditions interact with seagrass growth through feedback effects, and this interaction couples local conditions and light-temperature variation. This indirect link between light and temperature and local conditions may confound the interpretation of correlations between light and temperature and seasonal seagrass growth. Hence, the dominant role of light and temperature, interpreted to reflect direct effects in controlling seagrass seasonality, needs be re-evaluated to account for the importance of seasonal variability in local factors.

Acknowledgements. This work was supported by the grant STEP-0063-C of the ECC. We thank N. Lopez and M. A Mateo for therr help. Irradiance data were kindly provided by Fundació Mas Badia (Estació Experimental Agrícola).

\section{LITERATURE CITED}

Alef, K., Kleiner, D. (1986). Arginine ammonification, a simple method to estimate microbial activity potentials in soils. Soil Biol. Biochem. 18(2): 233-235

Aller, R. T (1980). Quantifying solute distributions in the bioturbated zone of marine sediments. Geochim. Cosmochim. Acta 44: 1955-1965

Bay, D. (1984). A field study of the growth dynamics and productivity of Posidonia oceanica (L.) Delile in Calvi Bay. Corsicd. Aquat. Bot. 20: 43-64

Buia, M. C., Zupo, V., Mazzella, L. (1992). Primary production and growth dynamics of Posidonia oceanica. P.S.Z.N. I: Mar. Ecol. 13(1): 1-15

Caye, G., Rossignol, M. (1983). Étude des variations saisonnières de la croissance des feuilles et des racines de Posidonia oceanica. Mar. Biol. 75: 79-88

Duarte, C. M. (1989). Temporal biomass variability and production/biomass relationships of seagrass communities Mar. Ecol. Prog. Ser. 51:269-276

Duarte, C. M. (1990). Seagrass nutrient content. Mar. Ecol. Prog. Ser. 67: 201-207

Duarte, C. M. (1991). Allometric scaling of seagrass form and productivity. Mar. Ecol Prog. Ser. 77: 289-300

Durako, M. J. (1993). Photosynthetic utilization of $\mathrm{CO}_{2 \text { (aq) }}$ and $\mathrm{HCO}_{3}{ }^{-}$in Thalassia testudinum (Hydrocharitaceae). Mar Biol. 115: 373-380

Fourqurean, J. W. (1992). Relationships between porewater nutrient and seagrasses in a subtropical carbonate environment. Mar. Biol. 114: 57-65

Grasshoff, K., Ehrhardt, M., Kremling, K. (1983). Methods of seawater analysis. Verlag Chemie, Weinheim

Hemminga, M. A., Harrison, P. G., Lent, F. v. (1991). The bal- ance of nutrient losses and gains in seagrass meadows Mar. Ecol. Prog. Ser. 71. 85-96

Hillman, K., Walker, D. I., Larkum, A. W. D., McComb, A. J. (1990). Productivity and nutrient limitation. In: Larkum, A W. D. McComb, E. A. J., Shepherd, S. A. (eds.) Biology of seagrasses. Elsevier, Amsterdam, p. 635-685

López, N. (1993). Actividades bacterianas del sedimento superficial marino y su importancia ecológica en la producción de los sistemas litorales. Ph.D. thesis, Universidad Politécnica de Barcelona

Marshall, P. A., Smith, R., Alberte, R. (1987). Glutamine synthetase activity and free aminoacids pools of eelgrass (Zostera marina L.) roots. J. exp. mar. Biol. Ecol. 106 $211-228$

Mateo, M. A., Sabaté, S. (1993). Wet digestion of vegetable tissue using a domestic microwave oven. Analyt. Chem. 279: $273-279$

Morris, J. T (1984). Effects of oxygen and salinity on ammonium uptake by Spartina patens (Aiton) Muhl. J. exp. mar Biol. Ecol. 78: 87-98

Morris, J. T., Dacey, W. H. (1984). Effects of oxygen on ammonium uptake and root respiration by Spartina alterniflora. Am. J. Bot. 71. 979-985

Orth, R. J., Moore, K. A. (1986). Effect of nutrient enrichment on growth of the eelgrass Zostera marina in the Chesapeake Bay, Virginia, U.S.A. Aquat. Bot. 24: 335-341

Ott, J. A. (1980). Growth and production of Posidonia oceanica (L.) Delıle. P.S.Z.N. I: Mar. Ecol. 1. 47-64

Pedersen, M. F., Borum, J. (1992). Nitrogen dynamics of eelgrass Zostera marina during a late summer period of high growth and low nutrient availability. Mar. Ecol. Prog. Ser. 80: $65-73$

Pérez, M., Romero, J. (1992). Photosynthetic response to light and temperature of the seagrass Cymodocea nodosa and the prediction of its seasonality. Aquat. Bot. 43: 51-62

Pérez, M., Romero, J., Duarte, C., Sand-Jensen, K. (1991). Phosphorus limitation of Cymodocea nodosa growth. Mar. Biol. 109: 129-133

Purc, H. (1985). Growth dynamics in Posidonia oceanica (L.) Delile. P.S.Z.N. I: Mar. Ecol. 6(2): 141-165

Powell, G. V. N., Kenworthy, W. J., Fourqurean, J W. (1989). Experimental evidence for nutrient limitation of seagrass growth in tropical estuary with restricted circulation. Bull. mar. Sci. 44(1): 324-340

Romero, J. (1989a). Primary production of Posidonia oceanica beds in the Medes Islands (Girona, NE Spain). In Boudouresque, C. F., Meinesz, A., Fresi, E., Gravez, V (eds.) International Workshop on Posidonia Beds. GIS Posidonie, Marseille, p. 63-67

Romero, J. (1989b). Seasonal pattern of Posidonia oceanica production: growth, age and renewal of leaves. In: Boudouresque, C. F., Meinesz, A., Fresi, E., Gravez, V. (eds.) International Workshop on Posidonia Beds. GIS Posidonie, Marseille, p. 63-68

Romero, J., Pergent, G., Pergent-Martini, C., Mateo, M. A. Regnier, C. (1992). The detritic compartment in a Posidonia oceanica meadow; litter features, decomposition rates and mineral stocks. P.S.Z.N. I.: Mar. Ecol. 13(1): 69-83

Sand-Jensen, K. (1975). Biomass, net production and growth dynamics in an eelgrass (Zostera marina L.) population in Vellerup Vig, Denmark. Ophelia 14: 185-205

Short, F. T (1987). Effects of the sediment nutrients on seagrasses: literature review and mesocosm experiment Aquat. Bot. 27: $41-57$

Sokal, R. R., Rohlf, F. J. (1981). Biometry. Freeman \& Co., New York

Sommers, L. E., Nelson, D. W. (1972). Determination of total 
phosphorus by a rapid perchloric acid procedure. Soil. Sci. Soc. Am. Proc. 36: 902-904

Vidal, M. (1988). Contenido y dinámica del fósforo en el sedimento de praderas de fanerógamas marinas. Oecologia aquat. 9: $41-59$

Wittman, J. C. (1984). Temporal and morphological variations of growth in a natural stand of Posidonia oceanica (L.) Delile. P.S.Z.N. I: Mar. Ecol. 5(4): 301-316

Yamada, H., Kayama, M. (1987). Liberation of nitrogenous

This article was submitted to the editor compounds from bottom sediments and effect of bioturbation by small bivalve, Theora lata (Hinds). Estuar. coast. Shelf. Sci. 24: 539-555

Zieman, J. C. (1974). Methods for the study of the growth and production of turtle grass, Thalassia testudinum König. Aquaculture 4: 139-143

Zieman, J. C. (1975). Seasonal variation of turtle grass, Thalassia restudinum König, with reference to temperature and salinity effects. Aquat. Bot. 1: 107-123

Manuscript first received: February 14, 1994 Revised version accepted: December 27, 1994 